クロロホルムーメタノール(98:2)溶什部からX $93 \mathrm{mg}$ (收率 9.3 \%)を得た。クロロホルムーメタノール(9:1)溶出部からメ而 $230 \mathrm{mg}$ (牧率 $23 \%$ ) 得た。

\subsubsection{1-(1'-イソキノリル)-4-キノロン(XXVI)の加水分解:}

XXY $100 \mathrm{mg}$ を 48\% 臭化水素酸に溶加し，封管中 $210^{\circ} \sim 220^{\circ} \mathrm{C}$

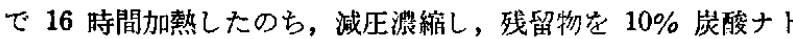
リウム水溶液でアルカリ性にしてふたたび隇圧で蒸発乾固，つい でクロロホルムで温浸, 乾燥, 溶媒留士, 残留物 $83 \mathrm{mg}$ をアル ミナクロマトグラフィーにより精製した。クロロホルムーメタノ 一ル(98:2)溶出部から Xh $27 \mathrm{mg}$ を得た。クロロホルムーメタノ ール(95:5)溶出部から姐 $26 \mathrm{mg}$ を得た。
終りに本研究に扣いて種々御指導いただいた東京大学名鲎教授 落合英二先生，御指道ならびに本論交の御校閲をしていただいた 大阪大学基礎工学部守谷一郎教授に澡甚の謝意を表わすととも に，終始御鞭撻を晹わった当社研究所長武田健一博士，研究員浜 元 要博士に愿く感謝致します。種々御助言をいただいた塞田種 一博士, 谷田 博博士, 打上び德山幹治博士に感謝致します。実 験に協力された故沉野实夫, 平田 勤, 池上昭子の各氏,ならび に元素分析，紫外吅よび赤外吸収スペクトルの測定をしていただ いた諸氏に感謝致します。

(1963 年 11 月, 化学関保学協会秋季研究発表大会講演)

\title{
フェニルプロピオール酸の部分水妻添加による cis-ケイ皮酸の合成*1
}

(昭和 39 年 6 月 3 日 受 理)

漆 原義之十・広田穣呫

\begin{abstract}
フェニルプロピオール酸のアセチレン結合をエチレン結合に還元するのに適当な水素化触媒を見いだす目的でフェニルプロピオ 一ル酸の接触水素添加の研究を各種のパラジムム触媒, ニッケル触媒，Adams の酸化白金触媒などを用いて行なった。触媒の選 択性は反応系の水素财叹量がちょうど $1 \mathrm{~mol}$ となったときに反応を中断し，フェニルプロピオール酸およびcis-ケイ皮酸を赤外吸 収スペクトル法により決定することにより調べた。他方，反応のはやさを反応時間に対してプロットして水素を $1 \mathrm{~mol}$ 吸収したを

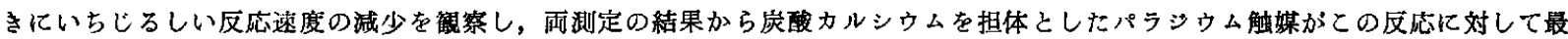
適であり，他のパラジウム触媒扰よびニッケル触媒もとの選択的還元に用い得るとと老結論した。
\end{abstract}

\section{1 緒需}

著者らがいまをで 6 報にわたり報告してきたケイ皮酸の多形の 実験において必要としたcis-ケイ皮酸類の命成法としては，各報 交りで述べたように二とおりの方泛方ある。第一のう法は対応す る trans 它皮酸をフェニルナ゚ロピオール酸として，それを部 分水素添加して cis-ケイ皮酸とするうう法であり，第二は刘応主る transーケイ皮酸の溶液に水銀灯などを用いて紫外線を照射して， cis 形と trans 形の平衡混合物としてその混合物から cis 形を分 別する方法である。しかし多形を生成させる実験においてはかな り多量のcis-ケイ皮酸を必要とするので, 第二の紫外線照射の方 法で十分な量の試料を会成与ることは困難であり，もっぱら第一

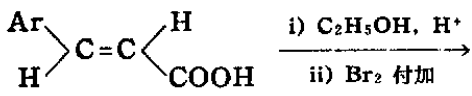

(trans 形)

$\operatorname{ArCHBrCHBrCOOC} \mathrm{H}_{5} \stackrel{\text { KOH- } \mathrm{C}_{2} \mathrm{H}_{5} \mathrm{OH}}{\longrightarrow}$

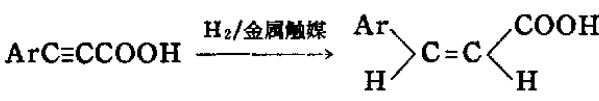
(cis 形)

図 1 cis-ケイ皮酸の合成

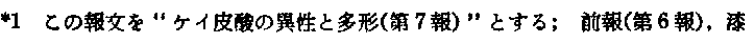
原, 伀田, 日化 82, 921(1961)、乙の研究仙東京大学理学部伒わいて行なわ れた.

$\dagger$ 上筧大学理学部, 新缩区四谷

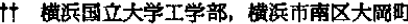

1) Y. Urushibara, M. Hirota, Bull. Chem. Soc. Japan 32, 703(1959); 漛源，広田，日化 B2，351，354，358(1961)。
の方法がとられる。この方法で問題となるのは最後にフェニルプ ロピオール酸它触媒による水素添加をして cis-ケイ皮酸とする段 階である。

この反応岋部分水素添加反応であるから，この反応に適する触 媒を使用しないとフェニルプロピオール酸をcis-ケイ皮酸にする 反応(図 $2 ， \mathrm{~A}$ )が選択的に起らず，cis-ケイ皮酸の生成にともな ってこれがさらにフェニルプロピオン酸に還元される反応(図 2 ， B)が起り，その結果水素 $1 \mathrm{~mol}$ を吸収したところで反応を停止 してあかなり多量の $\beta$ ーフェニルプロピオン酸および未反応のフ ェニルプロピオール酸を含む混合物を得ることがあり得る。反応 が中間の cis-ケイ皮酸の段階で停止せず 1 段階でフェニルプロピ オン酸となる機構をとるとすれば(因 $2 ， \mathrm{C}$ )，cis-ケイ皮酸はま ったく生成せず $50 \%$ の $\beta$ ーフェニルプロピオン酸と $50 \%$ のフ ェニルプロピオール酸が得られるという場合も考えられる。部分

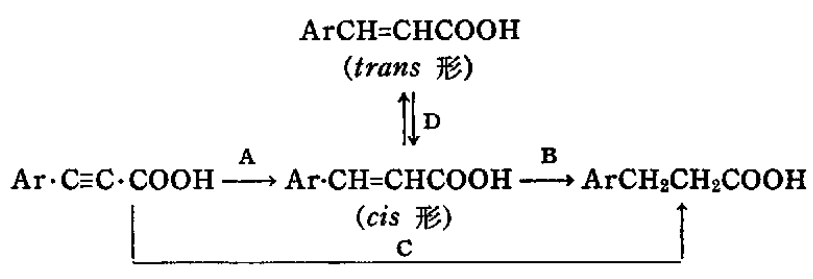

図2フェニルプロピオール酸の水素添加

水素添加によりヶイ皮酸の段階で停止するとしてもその立体化学 が問題であるが，接触水素添加では cis 付加が優勢であることは 多くの実例により経験的法則として確立されている。 このように考えると，この反応に使用する触媒として最適なる 
のを選択することは非常に大切なこととなってくる。それではこ の部分還元反忘に実際に使用されている触媒ではどのような結果 が得られているかを㛟討して見ると，この反応を最初に行なった のは $\mathrm{Paal}{ }^{2)}$ であり，彼はフェニルプロピオール酸ナトリウムの 水溶液をプロタルビン酸ナトリウムを保護コロイドとしたコロイ ド状パラジウム触媒を用いて還元して cis-ケイ皮酸を合成してい る。以後の研究者はいずれもこの触媒を用いて $c i s$-ケイ皮酸を合 成している。しかしこの触媒法調製がかなり面倒であること，水 溶液以外では使用できないこと，したがって重水素を用いる実験 に使用するに法交換できる水素をすべて重水素と交換した上で重 水溶液で水素添加觉行なうこと汇り，不便であることなどの久 点をむっている。そこでこの触媒のように選択性がよく，しかる 取り报いに便利な触媒を求める必要を生じた。この目的でパラジ ウムーケイソウ土,パラジウムー硫酸バリウム ${ }^{3)}$, 酶酸鉛で被毒した パラジウム-炭酸カルシウムなどの担体付パラジウム触媒, 䓇原 ニッケル $\mathrm{B}^{4)}$, ラネーニッケルらなどのニッケル触媒, Adams

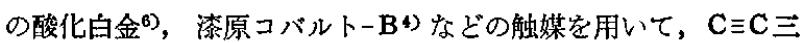
重結合を $\mathrm{C}=\mathrm{C}$ 二重結合に還元するのに適当な触媒をさがす目的 でフェニルプロピオール酸の接触水素添加を行ない，水素吸收速 度の反応開始後の時間による变化, および反忘の中間の段階にお ける生成物の赤外吸収スペクトルの測定を行ない，選択的な水素 添加が行なわれているかどうかを調べた。

\section{2 実験}

\section{1 接触水素添加の実験}

試料のフェニルプロピオール酸の合成は既知の方法(図 1 )によ り，触媒の調製む以前の研究者の報告にしたがっているのでここ ではとくに述べることをさける。触媒の調製について特記すべき 点注ニッケル触媒の場合多量の溶媒で空気と遮断された状態で数 日放置したものを使用したことであり，この処置は触媒活性の若 干の低下をもたらすが，測定した水素吸収速度のデータの再現性 に扮いてすぐれているためである。

接触水素添加はフェニルプロピオール酸ナトリウムの希水溶液 (1 $l$ 中にフェニルプロピオール酸として, 約 $29 \mathrm{~g}(0.2 \mathrm{~mol})$ を含 む)について常温常压でつリマゼ式装置を用いて行ない，気体ビ ニレットを用いて単位時間あたりの水素睖収量を測定した。

\section{2 赤外吸収スペクトルの測定}

反応途中で生成物の吸収スペクトルの測定を行なうために，水 素添加反応を一定体積の溶液について行ない，赤外吸収スペクト ルの測定を行なおうと欲するときに反応を一畹停止して(らり京 ぜを中止当机ば水素の供給が停止されて反応は停止する)，その ときでの水素吸収量堂記録し，反応液の一定量 $(5 \mathrm{cc})$ をピペッ トでわかちとり，ふたたび反応をつづける。わかちとった溶液を鉱 酸で酸性としてエーテル抽出を 3 度行ない，エーテル層を水洗し エーテルを蒸留し去る。残留物は多くの場合油状であるが,固体の 場合も晹浴上で温めると容易汇融解寸るので，乙れを岩塩板に摤 えで液体フィルムとして赫外吸收スペクトルの測定を行なった。

2) C. Paal, C. Amberger, Ber. 38, 1398(1905).

3) R. Mozingo, "Organic Syntheses" Vol. 20, John Wiley \& Sons, New York(1946)p. 77.

4) Y. Urushibara, S. Nishimura, Bull. Chem. Soc. Japan 27, 480 (1954).

5) S. Nishimura，ibid. 32，61(1959); および西村雷夫氏の助言による.

6) R. Adams, V. Voorhees, R. L. Shriner, "Organic Syntheses" Col. Vol. 1, John Wiley and Sons, New York(1948)p. 463.
赤外吸収スペクトルの测定は Baird B 型複光路赫外分光器, Infracord 複光路赤外分光器打よび日主. EPI-2 型複光路赤外分 光器学阙用した。

赤外吸収スペクトルを用いる定量は図 3 に示したフェニルプロ

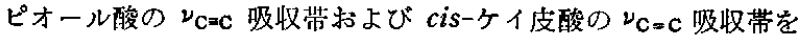
検量線として行ない， $\nu_{\mathrm{C}=\mathrm{c}}$ 吸收带については $\nu_{\mathrm{C}=\mathrm{O}}$ 吸収帯の重 なりに対する補.Eをした。この補正項の值はフェニルプロピオー ル酸，および cis-ケイ皮酸の $\nu_{\mathrm{C}}=0$ の四収強度 $\left(\varepsilon_{\max }\right)$ に大きな 差がないので雨者の混会物についても一定优を用いた。

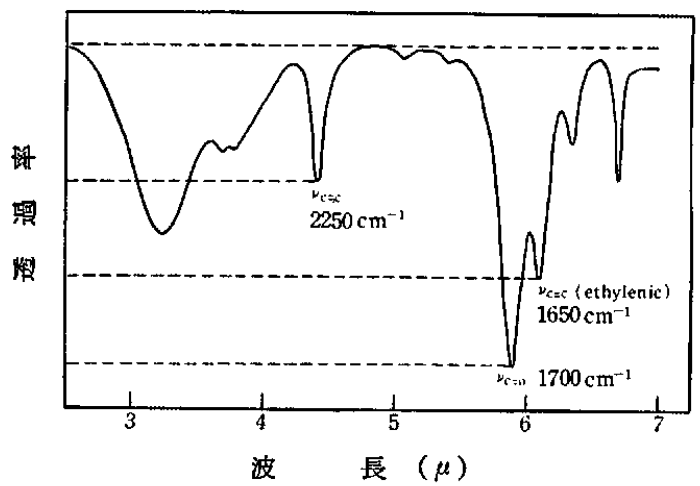

図 3 フェニルプロピオール酸の接触水素添加を 反応途中で停止して得られる反応泥合物の 赤外吸収スペクトルの例

\section{3 結果および考察}

フェニルプロピオール酸のアセチレン結合をエチレン結合に還 元する部分水素添加に対する触媒の選択性をを調べる日的で，ちょ うど $1 \mathrm{~mol}$ の水素を吸収したときに水素添加を中止して生成物の 赤外吸収スペクトルの測定を行ない，原料，cis-ケイ皮酸および $\beta$ ーフェニルプロピオン酸の含有最の決定岁行なった結果を表 1 に示す。図 3 に示すように $\nu_{\mathrm{C}=\mathrm{c}}$ 吸収带は他の吸収带の重なりが ないので検量線として適当であるが， $\nu_{\mathrm{c}=\mathrm{c}}$ 吸収带は強度の大き い到=0 吸收带と重なるのでそれに対する補正を加える必要があ り，補正をほどこしてもな和吸収極大位圆における吸光度による 定量では誤差が大きくなるので，主として $\nu_{\mathrm{C}=\mathrm{c}}$ を検星線として 用いて $\nu_{\mathrm{C}=\mathrm{c}}$ からの值を参考のために記した。

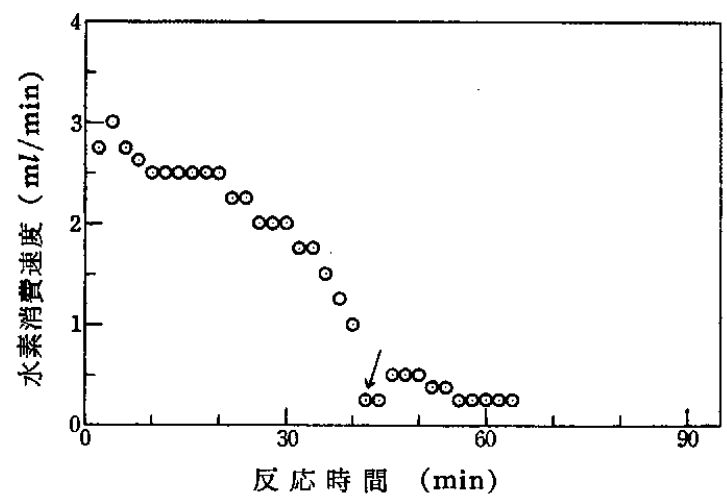

矢印はフェニルプロピオール酸と等もルの水素を 财収した点を示す．以下の図でも同じ。

図 4 酢酸鉛により被毒したパラジゥム/炭酸カルシウ ム触媒によるフェニルプロピオール被の僄元の際 の水素吸収量の時間による変化 
䒾 1 フェニルプロピオール酸の部分水素添加に対する各種の水素化触媒の選択性

(等モルの水素吸收時に反応を停止して生成物を定量した絬果を示す)

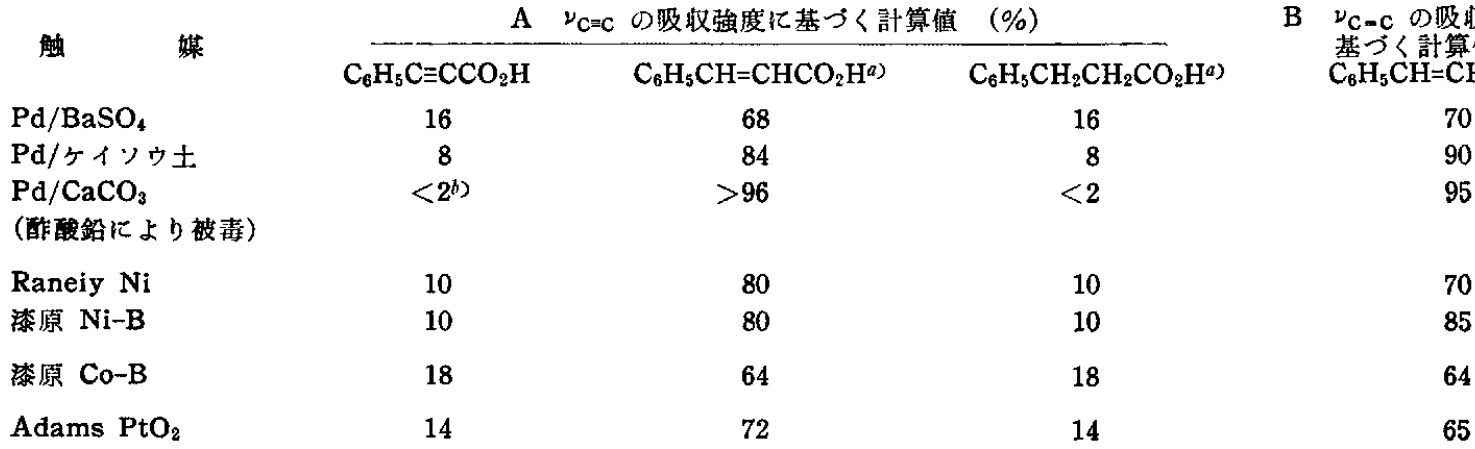

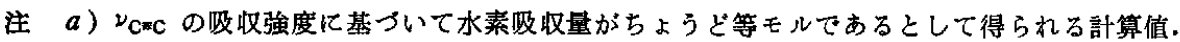

b) $\nu_{\mathrm{C} * \mathrm{C}}$ 吸收带は検出されないので存在したとしても $2 \%$ 以下である。

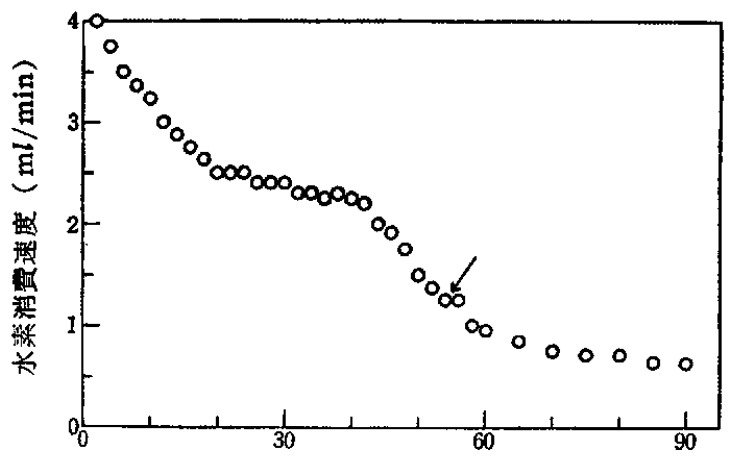

反応時間 $(\mathrm{min})$

図 5 パラジウム/ヶイソウ土触媒によるフェニルプロピ オール酸の還元の際の水素吸収量の時間による変化

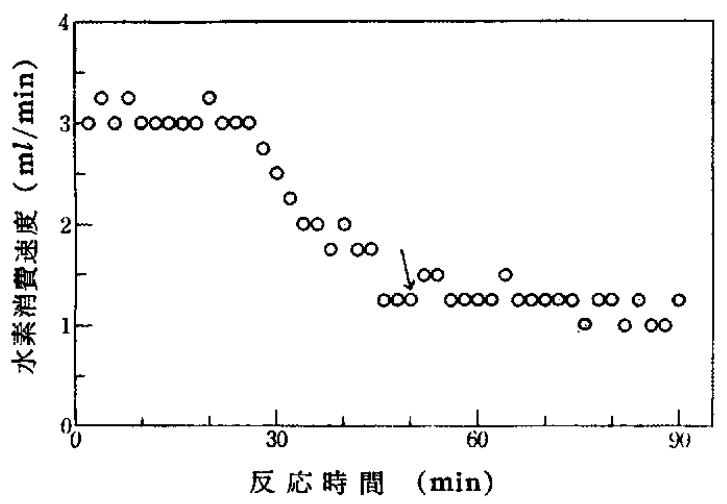

図6 ラネーニッケル触媒によるつェニルプロピオール 酸の罯元の際の水素吸収量の時間による变化

この結果から選択的にフェニルプロピオール酸をcis-クイ皮酸 に還元するには，炭酸カルシウムを担体としたパラシウム触媒を 酢酸鉛の水溶液で被毒したいわゆる Lindler 触媒が最適である が，その他のパラジウム触媒およびニッケル触媒では十分この目 的に供し得ることが知られた。

選択的水素添加を行なうために望ましい他の要件として部分的 水素添加の終了点を知ることが必要である。このために普通水素 吸収量に着目するが，水素吸収量を吸収体積から算出するために は反応系の温度変化を考虑する必要があり，また試料の正確な量 を知る必要があって，終了点の監視は面倒であるので，部分水素 添加を選択的に行ない，cis-ケイ皮酸の段階で反応が停止するよ うな触媒が理想的である。このような見地から水素吸収量の反応

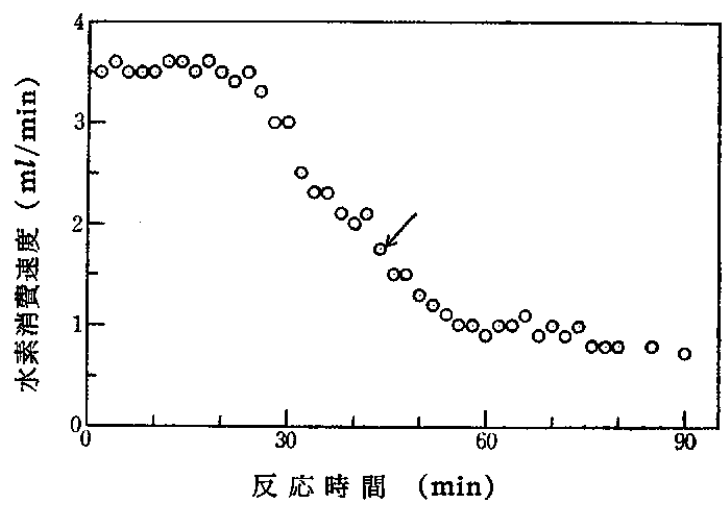

因 7 幥原ニッヶルーB 触媒によるフェニルプロピオー 儿酸の還元の際の水素吸収量の時間による変化

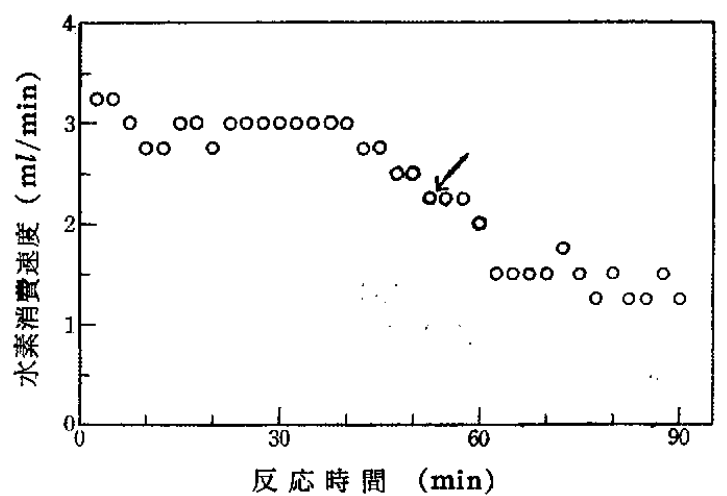

図 8 Adams の酸化白金触媒によるフェニルプロピオ 一ル酸の還元の際の水素吸収量の時間による変化

の進行にともなう変化学調べた結果を図4～8に示す。これらの 因で矢印は等モルの水素の吸收が終った点を示す。

この水素消費速度の変化の測定結果から，やはり被毒したパラ ジゥム/炭酸カルシウム触媒が最適であるととが知られたが, 他 のパラジウム触媒および漆原ニッケルB，ラネーニッケルなどの ニッケル触媒でもアセチレン結合とエチレン結合では水素添加速 度がかなり異なり，水素の消費速度の変化を観察することにより 部分還元の終了点を見いだすことも可能である。この実験結果に 対与る触媒反応の見地汃らの検討は別に発表する。

最後にこの研究に対して御助言を睗わった東京大学理学部大木 道則教授，扣よび東京農工大学西村重夫教授に感謝する。 